\title{
Milk and Serum Progesterone Levels in Mares after Ovulation
}

\author{
By Erkki Koskinen, Heli Lindeberg, Helena Kuntsi and Terttu Katila
}

Agricultural Research Centre, Equine Research Station, Ypäjä, and

College of Veterinary Medicine, Department of Clinical Veterinary Sciences, Hautjärvi, Finland.

\begin{abstract}
Koskinen, E., H. Lindeberg, H. Kuntsi and T. Katila: Milk and serum progesterone levels in mares after ovulation. Acta vet. scand. 1990, 31, 441-444. - Twentyfour Finnhorse mares were examined by rectal palpation and ultrasonography every $6 \mathrm{~h}$ during late oestrus to determine the time of ovulation. Milk and serum samples were collected every $6 \mathrm{~h}$ after the detected ovulation for progesterone analysis. The progesterone rises took place within $0-54 \mathrm{~h}$ and $0-60 \mathrm{~h}$ after ovulation, in milk and serum, respectively.

Statistically significant differences $(p<0.05)$ in progesterone levels were observed for the first time 12-18 h and 18-24 h after ovulation, in serum and milk, respectively, as compared to progesterone levels $0-6 \mathrm{~h}$ after ovulation.
\end{abstract}

timing ovulation; luteal activity.

\section{Introduction}

Although the pattern of progesterone changes in mare serum is well established (Sharp \& Black 1973, Allen \& Hadley 1974, Evans \& Irvine 1975), sampling was not frequent enough in most studies for adequate characterization of the progesterone curve, especially immediately after ovulation.

Most studies have shown that progesterone levels increase within $24-36 \mathrm{~h}$ of ovulation (Stabenfeldt et al. 1971, Plotka et al. 1972, Allen \& Hadley 1974, Ginther 1979). Sharp \& Black (1973) reported that progesterone concentration 1.1 days after the end of heat was $100 \%$ greater than that during the previous day. In their study, however, the mares were not palpated, and the time of ovulation was therefore not confirmed. On the basis of daily blood sampling, Makawiti et al. (1983) found that a progesterone rise above baseline occurred on the day of ovulation. In contrast, Noden et al. (1975) observed the first significant rise on the first day of dioestrus. According to Plotka et al.
(1975), the first increase in progesterone level took place $10 \mathrm{~h}$ after ovulation. Although blood samples in that study were collected every $2 \mathrm{~h}$, the mares were examined only once a day, which did not allow accurate timing of ovulation. Pipkin et al. (1987) reported that mean serum progesterone concentration increased $(p<0.05)$ within $12 \mathrm{~h}$ of ovulation. In their study, the mares were examined twice a day but the results do not indicate clearly whether the progesterone rise took place $0-12 \mathrm{~h}$ or $12-24 \mathrm{~h}$ after ovulation.

In milk progesterone studies, sampling intervals have either not been short enough for accurate demonstration of rises in progesterone after ovulation (Bailes \& Holdsworth 1978 ) or ovulation has not been confirmed by rectal palpation (Laitinen et al. 1981). Hunt et al. (1978) determined progesterone levels in milk and plasma 3 times a week. Progesterone patterns were similar in milk and plasma. The correlation coefficient for 362 paired samples was 0.7. Stolla et al. 
(1980) collected milk samples daily from an unrecorded number of mares. However, blood samples were taken simultaneously from only 1 mare.

Rises in progesterone levels in serum and, more particularly, in milk shortly after ovulation have not been precisely described. The study reported here was designed in such a way that the mares were examined for ovulation every $6 \mathrm{~h}$, and milk and blood samples were collected simultaneously with examination.

\section{Materials and methods}

Twenty-four Finnhorse mares were studied. Their average age was 9.8 years (range 4-23 years). The mean number of foalings was 3.5 (range 1-10). The mares had foaled between mid-April and late July. They were kept on pasture until the experiment began at the beginning of June. The first post partum oestruses were excluded from the study. The mares were housed in separate stalls during the examinations.

The start of the follicular phase was detected by progesterone analysis of thrice-weekly milk and serum samples. Progesterone concentrations in serum and whole milk were determined by the direct radioimmunoassay (RIA) method. The standards in the serum and milk kits were based on buffer and mare's milk, respectively'.

Daily rectal palpation began once the progesterone level had fallen to $1 \mathrm{nmol} / \mathrm{l}^{2}$. On detection of a mature follicle (diameter $\geq$ $3.5 \mathrm{~cm}$ ), rectal palpation and ultrasound scanning were performed every $6 \mathrm{~h}$ to determine the time of ovulation to within $6 \mathrm{~h}$. Milk and blood samples were collected simultaneously with rectal palpations every 6 $\mathrm{h}$ for 3 days after ovulation, in some mares for even longer, until a marked rise in progesterone occurred.

Statistical analysis of the data was performed using the paired t-test. Every subsequent progesterone level of each individual was compared with the level of individual's 0-6 h sample.

1 Farmos Diagnostica, Turku, Finland.

$21 \mathrm{nmol} / \mathrm{l}$ corresponds to $0.315 \mathrm{ng} / \mathrm{ml}$.

Table 1. Cumulative percentage rises in progesterone $(>1$ $\mathrm{nmol} / \mathrm{l})$ in mare serum and milk $(\mathrm{n}=24)$.

\begin{tabular}{|c|c|c|c|c|}
\hline \multirow[b]{2}{*}{$\begin{array}{l}\text { Hours after } \\
\text { ovulation }\end{array}$} & \multicolumn{2}{|c|}{ SERUM } & \multicolumn{2}{|c|}{ MILK } \\
\hline & $\begin{array}{l}\text { Numbers } \\
\text { of mares }\end{array}$ & $\begin{array}{l}\text { Cumulative } \\
\text { percentage } \\
\text { rises in } \\
\text { progesterone }\end{array}$ & $\begin{array}{l}\text { Numbers } \\
\text { of mares }\end{array}$ & $\begin{array}{l}\text { Cumulative } \\
\text { percentage } \\
\text { rises in } \\
\text { progesterone }\end{array}$ \\
\hline $0-6$ & 2 & 8 & 2 & 8 \\
\hline $6-12$ & 1 & 13 & 1 & 13 \\
\hline $12-18$ & 5 & 33 & 3 & 25 \\
\hline $18-24$ & 7 & 63 & 4 & 42 \\
\hline $24-30$ & 4 & 79 & 4 & 58 \\
\hline $30-36$ & 2 & 88 & 6 & 83 \\
\hline $36-42$ & 1 & 92 & 2 & 92 \\
\hline $42-48$ & 1 & 96 & 1 & 96 \\
\hline $48-54$ & 0 & 96 & 1 & 100 \\
\hline $54-60$ & 1 & 100 & 0 & 100 \\
\hline
\end{tabular}




\section{Results}

The first detectable rise in progesterone level ( $\geq 1 \mathrm{nmol} / \mathrm{l}$ ) occurred within 54 and $60 \mathrm{~h}$, in milk and serum, respectively (Table 1). Only 3 mares exhibited a serum progesterone rise within $12 \mathrm{~h}$. Three other mares exhibited increased progesterone values in milk within the same period. Twenty-four hoưrs after ovulation, $63 \%$ and $42 \%$ of the mares exhibited progesterone concentration of over $1 \mathrm{nmol} / \mathrm{l}$, in serum and in milk, respectively. First statistically significant differences $(p<0.05)$ from progesterone levels 0-6 $\mathrm{h}$ after ovulation were detected 12-18 and 18-24 $\mathrm{h}$ after ovulation, in serum and milk, respectively. In $50 \%$ of the mares, progesterone concentrations increased earlier in serum than in milk, in $29 \%$ earlier in milk and in $21 \%$ they increased at the same time in both.

Although there was a significant $(\mathrm{p}<0.05)$ correlation between milk and serum levels (correlation coefficient 0.7 ), progesterone values were consistently higher in serum than in milk more than $12 \mathrm{~h}$ after ovulation (Table 2).

\section{Discussion}

Our results support the general view that progesterone levels rise within $24-48 \mathrm{~h}$ of ovulation. In our study, 2 mares out of 3 exhibited a rise in serum progesterone levels within $24 \mathrm{~h}$. An interesting finding was that some mares exhibited elevated serum progesterone levels later than 2 days after ovulation.

Progesterone determinations cannot be used to predict ovulation accurately but could be used for deciding when to stop insemination. In the study reported here, the time from ovulation to the first detectable rise in progesterone level varied considerably among mares. This means that it is impossible to estimate the exact time of ovulation on the basis of a rise in progesterone level in any mare. Progesterone determination is a useful adjunct to rectal palpation but had detection of a rise in progesterone level to $1 \mathrm{nmol} / 1$ or above been used as the sole criterion for deciding when to stop insemination, $37 \%$ or $58 \%$ of the mares (depending on whether serum or milk progesterone levels had been determined) would have been inseminated

Table 2. Increases in progesterone concentrations $(\mathrm{nmol} / \mathrm{l})$ in comparison with post-ovulatory sample. (Concentration in sample - concentration in individual's sample $0-6$ hours after ovulation; $n=24$ ).

\begin{tabular}{|c|c|c|c|c|c|c|}
\hline \multirow[b]{2}{*}{$\begin{array}{l}\text { Hours after } \\
\text { ovulation }\end{array}$} & \multicolumn{3}{|c|}{ Serum progesterone concentration } & \multicolumn{3}{|c|}{ Milk progesterone concentration } \\
\hline & $\begin{array}{l}\text { Average } \\
\text { increase }\end{array}$ & $\begin{array}{r}95 \% \mathrm{c} \\
\text { interval }\end{array}$ & $\begin{array}{l}\text { fidence } \\
\text { or means }\end{array}$ & $\begin{array}{l}\text { Average } \\
\text { increase }\end{array}$ & $\begin{array}{r}95 \% \\
\text { interva }\end{array}$ & $\begin{array}{l}\text { fidence } \\
\text { or means }\end{array}$ \\
\hline & & & & & & \\
\hline $6-12$ & 0 & 0 & 0.4 & 0 & 0 & 0.8 \\
\hline $12-18$ & 1.0 & 0.3 & 1.7 & 0.6 & 0 & 1.6 \\
\hline $18-24$ & 2.0 & 0.7 & 3.3 & 1.3 & 0 & 2.2 \\
\hline $24-30$ & 3.0 & 1.6 & 4.4 & 1.4 & 0 & 2.3 \\
\hline $30-36$ & 4.0 & 2.4 & 5.5 & 2.8 & 1.1 & 4.1 \\
\hline $36-42$ & 6.3 & 3.8 & 8.9 & 4.4 & 2.4 & 5.8 \\
\hline $42-48$ & 8.0 & 4.9 & 11.2 & 5.1 & 2.9 & 6.7 \\
\hline $48-54$ & 9.4 & 6.7 & 12.2 & 5.5 & 4.1 & 6.8 \\
\hline $54-60$ & 11.5 & 8.8 & 14.3 & 7.6 & 6.3 & 9.0 \\
\hline $60-66$ & 12.9 & 10.2 & 15.6 & 9.2 & 7.8 & 10.5 \\
\hline
\end{tabular}


$24 \mathrm{~h}$ or more after ovulation. Although pointless in terms of conception, such late insemination is not necessarily harmful, if semen collection and insemination are carried out hygienically.

Serum progesterone determinations have been used in embryo transfer programmes to determine times of ovulation and, accordingly, of flushing. However, the results reported here indicate that the substantial variations in the initial progesterone rise after ovulation can lead to a discrepancy of more than 2 days in determination of the time of ovulation.

Serum progesterone rises earlier, and to higher levels, than milk progesterone. It is, therefore, recommended that serum progesterone levels rather than milk progesterone levels be determined in mares. However, if blood sampling presents a problem, milk progesterone determinations are a good alternative in mares with a foal at foot.

\section{References}

Allen WE, Hadley JC: Blood progesterone concentrations in pregnant and non-pregnant mares. Equine vet. J. 1974, 6, 87-93.

Bailes G, Holdsworth J: Progestagens in mares' milk. Brit. vet. J. 1978, 134, 214-215.

Evans MJ, Irvine CHG: Serum concentrations of FSH, LH and progesterone during the oestrous cycle and early pregnancy in the mare. J. Reprod. Fert. 1975, Suppl. 23, 193-200.

Ginther OJ: In: Reproductive Biology of the Mare. McNaughton and Gunn, Inc., Ann Arbor, Michigan 1979, p. 174.

Hunt B, Lein DH, Foote RH: Monitoring of plasma and milk progesterone for evaluation of postpartum estrus cycles and early pregnancy in mares. J. Amer. vet. med. Ass. 1978, 172, 1298-1302.

Laitinen J, Remes E, Hänninen $O$, Alanko M, Simanainen $V$ : Oestrus and pregnancy diagnosis by milk progesterone assay in the mares. Brit. vet. J. 1981, 137, 478-484.

Makawiti DW, Allen WE, Kilpatrick MJ: Changes in oestrone sulphate concentrations in peripheral plasma of pony mares associated with follicular growth, ovulation and early pregnancy. J. Reprod. Fert. 1983, 68, 481-487.

Noden PA, Oxender WD, Hafs $M D$ : The cycle of estrus, ovulation and plasma levels of hormones in the mare. J. Reprod. Fert. 1975, Suppl. 23, 189-192.

Pipkin JL, Forrest DW, Potter GD, Kraemer DC, Wilson JM: Plasma steroid concentrations after conception in mares. J. Reprod. Fert. 1987, Suppl. 35, 711-714.

Plotka ED, Witherspoon DM, Foley CW: Luteal function in the mare as reflected by progesterone concentrations in peripheral blood plasma. Amer. J. vet. Res. 1972, 33, 917-920.

Plotka ED, Foley CW, Witherspoon DM, Schmoller $G C$, Goetsch $D D$ : Periovulatory changes in peripheral plasma progesterone and estrogen concentrations in the mare. Amer. J. vet. Res. 1975, 36, 1359-1362.

Sharp DC, Black DL: Changes in peripheral plasma progesterone throughout the oestrus cycle of the pony mare. J. Reprod. Fert. 1973, $33,535-538$.

Stabenfeldt GH, Hughes JP, Evans JW, Ovarian activity during the estrous cycle of the mare. Endocrinology 1971, 90, 1379-1384.

Stolla $R$, Günzel $A-R$, Bader $H$ : Control of ovarian activity by milk progesterone determination in mares. 9th Int. Congr. Anim. Reprod. \& A. I., Madrid 1980, 206-209.

\section{Sammanfattning}

Progesteronnivåerna i serum och mjölk

hos ston efter ovulationen.

Tidpunkten för ovulationen hos 24 Finska kallblodston fastställdes genom rektalpalpation och ultraljudundersökning utförda var sjätte timme under sen estrus. Under tidig diestrus insamlades mjölk och serum prover för progesteron analyser. Progesteronnivåerna steg inom 0-54 och 0-60 timmar i mjölk respektive serum.

Statistiskt signifikanta skillnader $(\mathrm{p}<0.05)$ i progesteronnivåerna konstaterades 12-18 timmar och 18-24 timmar efter ovulationen i serum respektive mjölk jämförda med progesteronnivåerna $0-6$ timmar efter ovulationen.

(Received October 29, 1989; accepted January 17, 1990).

Reprints may be requested from: Erkki Koskinen, Horse Research Station, SF-32 100 Ypäjä, Finland. 